\title{
Seroprevalence of Bovine Viral Diarrhea Virus (BVDV) and Its Associated Risk Factors in Dairy Cattle in and Around Assela Town, South East Ethiopia
}

Pawlos Asnake ( $\sim$ pwasihun@gmail.com )

Haramaya University

Abdissa Lemma

Oromia livestock and Fishery development office of Tiyo district, Arsi Zone, Oromia region

Asamnew Tesfaye

National Animal Diagnostic and Investigation Center (NAHDIC)

Daneil Gizaw

National Animal Diagnostic and Investigation Center (NAHDIC)

Sintayehu Guta

National Animal Diagnostic and Investigation Center (NAHDIC)

Chala Dima

National Animal Diagnostic and Investigation Center (NAHDIC)

Fanos Tadesse

Addis Ababa University, School of Veterinary medicine

\section{Research Article}

Keywords: Bovine Viral Diarrhea Virus, Seroprevalence, Indirect ELISA, Ethiopia

Posted Date: December 28th, 2020

DOI: https://doi.org/10.21203/rs.3.rs-128860/v1

License: (c) (1) This work is licensed under a Creative Commons Attribution 4.0 International License.

Read Full License 


\section{Abstract}

Background: Bovine viral diarrhea (BVD) is one of the most economically important diseases of cattle population worldwide and caused by Bovine viral diarrhea virus (BVDV). A cross-sectional study was conducted from October, 2019 to April, 2020 to investigate the sero-prevalence and associated risk factors for Bovine Viral Diarrhea Virus (BVDV) infection. in and around Asella town, Ethiopia. Semi structured questionnaire survey was designed to assess the different variables related to herd managements through personal interview of the farmers. Serum samples were collected from a total of 45 non-vaccinated cattle herds (225 individual cattle) during the study period. Samples were examined for detection of bovine viral diarrhea virus (BVDV) antibodies using indirect enzyme-linked immunosorbent assay (iELISA) kit (ID Screen ${ }^{\circledR}$ BVD p80 Antibody) following the manufacturers protocol. Chi-square analysis and multivariable logistic regression model were used to identify risk factors for BVDV seropositivity.

Results: In the present study, 8.4\% (95\% Cl: 5.2-12.9) and 22.2\% (95\% Cl: 11.2-37.1) seroprevalence of BVDV antibody was observed at individual and herds level, respectively. Among the animal and management risk factors observed in multiple logistic regression analysis, higher seroprevalence of was observed in cows with history of abortion $53.8 \%$ (95\% Cl: 25.1-80.8\%), cattle reared in semi intensive farming system $28.3 \%$ (95\% Cl: 16.0-43.5) ( $P<0.05)$. In this study, abortion (adjusted OR: $30.5, P<0.05)$, repeated breeder (adjusted OR: 6.95, $\mathrm{P}<0.05$ ) and intensive farming systems (adjusted OR: 0.13, $\mathrm{P}<0.05$ ) were identified as potential variables for the seroprevalence of BVDV.

Conclusion: The study revealed immense exposure of cattle in and around Asella town to BVDV infection that varied with reproductive problem and farming system of the animals. Further studies will be required to elucidate the molecular epidemiology of BVDV infection in cattle and other livestock species in the study area.

\section{Background}

Bovine viral diarrhea (BVD) is an economically important disease in most cattle producing countries all over the world [1,2]. The disease has significant economic losses, both directly through high morbidity and mortality rates, increased premature culling, loss of milk production and reduced reproductive performance $[3,4]$ and indirectly through the cost of expenditure for control and eradication programs $[5$, $6,7]$. BVDV is an enveloped, small (12.5 kb) single stranded plus sense RNA virus that belongs to the family Flaviviridae grouped under genus Pestivirus [8]. The type I and II forms of BVDV are the distinct species or genotypes of BVDV and differentiated from each other and from other Pestiviruses by monoclonal antibodies directed against the E2 protein, or by genetic analysis of different regions of the genome [9]. Furthermore, according to their biotype, BVDV can also be further classified into cytopathic (CP) and non-cytopathic (NCP) based on in vitro cell culture characteristics and genetic differences [10, $11]$. 
Cattle are the natural host for BVDV and oro-nasal uptake of BVDV is the most frequent route of natural infection [12]. An infected herd and direct contact with persistently infected (PI) animals serve as the main source of transmission for the disease as they secrete and excrete a large amount of NCP BVD virus throughout their lives and unable to develop antibodies to BVDV. Indirect transmission may happen through the use of contaminated equipment or through insemination with BVDV infected semen [13]. Intrauterine infection of the fetus with NCP BVD virus in dairy and beef calves lead to abortion, still birth, congenital malformations of offspring, embryonic or fetal resorption manifesting as repeat breeding, mummification and birth of persistently infected calves or calves of poor vigor $[14,15]$.

Several diagnostic tests are available for detection of Bovine Viral diarrhea virus. In general, the BVDV diagnostic test can be classified to determine infectious virus or viral component as an indicator of active infection and to detect antibodies against BVDV indicating a previous exposure [16, 17]. Virus isolation, antigen capture ELISA and polymerase chain reaction (PCR) is the commonly used direct methods of BVDV detection [18]. NS3 (p80) and $E^{\text {rns }}\left(E^{0}\right)$ are the two BVDV proteins that are identified as potential target antigens. Knowledge of the herd management and environmental factors that increase the risk of BVDV infection would make better ability to control and prevent transmission, thereby minimizing unfavorable effects of BVDV infection on herd health and productivity [19]. The major strategies for prevention control of BVDV include identification and elimination of persistently infected (PI) animals, enhanced immunity through vaccination; and implementation of biosecurity measures $[20,21]$.

In Ethiopia, the first serological study of BVDV prevalence of $9.59 \%$ was reported by [22]. Later, $11.7 \%$ and $32.9 \%$ prevalence of BVDV was reported by $[23,24]$ among dairy cattle in Central and Southern Ethiopia, respectively. In a recent study, a prevalence of $32.6 \%$ and $51.7 \%$ were reported by $[25,26]$ in three milk shed of central and southern Ethiopian and Jimma town, respectively. These indicated that only limited studies were conducted on sero-prevalence of BVDV in the country. Therefore, the objectives of this study were to estimate the seroprevalence and to identify the potential risk factors of Bovine viral diarrhea virus (BVDV) in cattle in and around Assela town, Ethiopia.

\section{Methods}

\section{Study Area}

The study was carried out in and around Asella town, located $175 \mathrm{~km}$ South East of Addis Ababa from October, 2019 -April, 2020. The area is situated between $7^{\circ} 46^{\prime} \mathrm{N}$ latitude and $39^{\circ} 16^{\prime} \mathrm{E}$ longitudes at an altitude of 2430 meters above sea level (masl) in central high land of Ethiopia (Figure 1). It has an annual rainfall of $1147 \mathrm{~mm}$ of which more than $80 \%$ is in the long rainy season is distributed between (Junes to October). The mean annual minimum and maximum temperatures are $8.6^{\circ} \mathrm{C}$ and $21.6^{\circ} \mathrm{C}$ respectively.According to CSA, the total livestock population in Oromia region of Ethiopia is estimated to be about 24.43 million cattle, 9.39 million sheep and 8.59 million goat, 1.13 million horse, 134,898 mule, 3.42 million donkey, 315, 482 camel, and 19.02 million poultry [27]. The estimated livestock populations in Asella town and surrounding areas is about 151,821 heads of cattle, 94,565 heads of sheep, 16,774 
heads of goats, 37,093 heads of equine, 107,513 heads of poultry [28]. The livestock production systems in the region is dominantly a subsistence crop-livestock mixed system.

\section{Study population and study sample}

The study population consisted of dairy farms composed of cross breeds and local breeds cattle located in and around Asella town. Farms with small (1-10 animals) and medium (11-25 animals) sizes were eligible for participation. Farms of different kinds ranging from dairy farms managed with family labor in small settings to public or privately owned medium scale farms intended for commercial dairy production. The husbandry practice was, cows were hand milked twice per day and both natural mating and Al breeding systems were practiced in the study area. There was no vaccination program against BVDV and farmers took their animals for treatment whenever animals are diseased.

\section{Study Design, Sampling strategy and sample size calculation}

Cross-sectional study design was conducted from October, 2019-April, 2020 in randomly selected 45 farms/herds out of 270 registered dairy farms in and around Asella town [28]. All cattle above six months of age were included for this study. Relevant individual animal data and farm level information were collected using farmers interview through a semi-structured questionnaire. Depending on the herd sizes, herds were classified into two categories (I-herds with 1-10 animals and II- herds with 11-25 animals). Animals were also grouped into two age categories (young and adult whereas young is 6-18 months. A two stage cluster sampling method was used to determine the number of herds required during the study.

The sample size was determined based on previous BVDV prevalence of $32.6 \%$ in intensive dairy farms at central part of Ethiopia [25] with 95\% confidence interval and 10\% absolute precision [29]. Accordingly, 45 herds (225 individual animals were sampled (equation 1).

$$
\begin{gathered}
g=\frac{1.96^{2} \times \mathrm{D} \times \operatorname{exP}(1-\mathrm{exP})}{\mathrm{b} \times \mathrm{d}^{2}} \\
\mathrm{~g}=\frac{1.96^{2} \times 2.68 \times 0.326(1-0.326)}{5 \times 0.1^{2}}=45 \\
\mathrm{n}=\mathrm{b} \times \mathrm{g}, \quad 5 \times 45=225
\end{gathered}
$$

Where, $\mathrm{g}=$ number of cluster to be sampled; exP = Expected prevalence $(32.6 \%) ; z=1.96=95 \%$ confidence statistic and $d=$ desired absolute Precision $10 \%=0.1 ; D=$ design effect $=2.68$ which was calculated by using a formula $D=\rho(b-1)+1 . b=$ an average number of cattle per cluster sampled $(b=5)$ which was assumed by the investigator, an intra-cluster correlation coefficient of $\rho=0.42$ was reported for BVD in cattle [30].

\section{Questionnaire survey}

Questionnaire survey was conducted to obtain appropriate information about the herd and individual dairy cattle. The questionnaire or data collection format contained information on the name of the farm, 
individual house hold farmer, location, Age, sex, breed, parity, history of reproduction problem, herd size, introduction of new animals, farming system and breeding methods.

\section{Blood Samples and serology assay}

Blood samples were collected from jugular vein using plain vacutainer tubes with needles. From each randomly selected animals, 5-6 ml of blood was drawn and kept overnight in an upright position followed by centrifugation at $1500 \mathrm{rpm}$ for $10 \mathrm{~min}$. The serum samples were decanted into labeled sterile cryovial tubes and stored at $-20^{\circ} \mathrm{C}$ at Asella regional laboratory. Then samples were transported using cool box with ice pack to National Animal Health Diagnostic and Investigation center (NAHDIC) laboratory to conduct the serological analysis. The presence of antibodies to BVDV was tested using an indirect Enzyme-Linked Immunosorbent Assay (iELISA)-targeting antibodies against BVD p80 Antibody (ID vet, Grabeis, France) according to the manufacturer instruction. Any herd with at least one seropositive animal was categorized as a positive herd.

Briefly, each blood serum sample was diluted in a $1 \mathrm{ml}$ dilution buffer, and the positive serum was resuspended in $1 / 100$ and distributed at $100 \mu \mathrm{l}$ in micro plate wells. The plate was incubated at $21^{\circ} \mathrm{C}$ for one hour. After incubation, the plate was rinsed three times with washing solution, and $100 \mu$ l of dilute conjugate solution was added to each well. The plate was incubated for 1 hour at $21^{\circ} \mathrm{C}$. Next, the plate was washed three times and $100 \mu \mathrm{l}$ of chromogen solution was added to each well. After incubation for 10 minutes at room temperature $(21 \otimes C)$, with protection from light, the reaction was stopped with $50 \mu \mathrm{l}$ of stop solution. Then, BioTek EL800 Microplate Reader used to measure the optical density (OD) of each sample and controls. A serum with absorbance value (S/P) with a cut-off level of 0.4 was considered to be BVDV positive. The serum absorbance value in between 0.4 and 0.5 were considered as doubtful and value greater than 0.5 were considered as negative according to the manufacturer of the ELISA kit.

\section{Data Storage, management and Analysis}

Data generated from questionnaire survey and laboratory investigations were recorded and coded using Microsoft ${ }^{\circledR}$ Excel for Windows 2010 and transferred to Statistical Product and Service Solutions (SPSS) version 20.0 (IBM SPSS, 2011). Chi-square test was conducted to determine the association between the BVDV status of the animals and the risk factors (sex, age, breed, parity, herd size, breeding systems, introduction of new animals, reproductive problem, farming system). Differences among groups of each factor were considered significant at $p<0.05$ for all parameters tested. Regression analysis was employed to establish the association between sero-positive result for bovine viral diarrhea virus and risk factors. Before regression analysis, the data was cheeked for fulfillments of assumptions, such as correlation of each variables (not more than 0.7 ), correlation of independent variables with dependent variable (minimum of 0.3), and multi-collinearity tests using Variance inflation factors (VIF) greater than 10 and Tolerance value less than 0.1 [31]. The strength of the association between outcome and explanatory variables was assessed using the crude and adjusted odds ratios (OR). Multivariable logistic regression procedures were used to model the effects of potential risk factors on outcome variables (BVDV 
antibodies). The forward elimination procedure was used to eliminate the factors that were not significant at $p<0.05$ in the overall model. Factors that were significant $(P<0.05)$ were retained in the final model and model fit was examined by post-estimation goodness-of-fit tests, namely the HosmerLemeshow test [32]. Finally, those variables with $\mathrm{P}<0.05$ (adjusted $\mathrm{OR}, 95 \% \mathrm{Cl}$ ) were considered as a significant potential risk factors for BVDV antibody seropositive results.

\section{Results}

\section{Sero-prevalence of BVDV}

From the 225 tested serum samples of cattle, 19 (8.4\%) (95\% Cl: 5.2-12.9) were positive for antibodies against BVDV using indirect antibody ELISA technique. Out of 45 cattle herds, 10 (22.2\%) (95\% Cl: 11.237.1) had at least one seropositive animal for BVDV antibody. The sero-prevalence of BVDV was significantly different $(P<0.05)$ between breeding type, and among farming systems and status of reproductive health. Even though there was no significant difference between or among other variables, prevalence of BVD was relatively higher in female animals (9.3\% [95\% Cl: $5.7-14.2])$, young age (12.5\% [95\% Cl: 6.6-20.8]), nuliparous (11.3\% [95\% Cl: 5.9-18.94]), farms with $11-25$ animals (44.4\% [95\% Cl: 25.5-64.7]) and farms introduced new animals to herds (10.2\% [95\% Cl: 6.1-15.6]) (Table 1). 
Table 1

Prevalence of BVDV and its association of different categorical variables in cattle

\begin{tabular}{|c|c|c|c|c|c|c|}
\hline \multirow[t]{2}{*}{ Variable } & \multirow[t]{2}{*}{ Categories } & \multirow{2}{*}{$\begin{array}{l}\text { No. of } \\
\text { examined } \\
\text { animals }\end{array}$} & \multirow{2}{*}{$\begin{array}{l}\text { No. of } \\
\text { Positive } \\
\text { Animals }\end{array}$} & \multirow{2}{*}{$\begin{array}{l}\text { Prevalence } \\
(95 \% \mathrm{Cl})\end{array}$} & \multicolumn{2}{|c|}{$\chi 2$ analysis } \\
\hline & & & & & $\begin{array}{l}\chi^{2} \\
\text { value }\end{array}$ & $\begin{array}{l}\text { p- } \\
\text { value }\end{array}$ \\
\hline \multirow[t]{2}{*}{ Sex } & Female & 204 & 19 & $\begin{array}{l}9.3 \%(5.7- \\
14.2)\end{array}$ & \multirow[t]{2}{*}{2.136} & \multirow[t]{2}{*}{0.229} \\
\hline & Male & 21 & 0 & $\begin{array}{l}0.0 \%(0.0- \\
0.0)\end{array}$ & & \\
\hline \multirow[t]{2}{*}{ Age } & Adult & 129 & 7 & $\begin{array}{l}5.4 \%(2.2- \\
10.9)\end{array}$ & \multirow[t]{2}{*}{3.562} & \multirow[t]{2}{*}{0.059} \\
\hline & Young & 96 & 12 & $\begin{array}{l}12.5 \% \\
(6.6-20.8)\end{array}$ & & \\
\hline \multirow[t]{2}{*}{ Breed } & Local & 41 & 3 & $\begin{array}{l}7.3 \%(1.5- \\
19.92)\end{array}$ & \multirow[t]{2}{*}{0.082} & \multirow[t]{2}{*}{1.00} \\
\hline & Cross & 184 & 16 & $\begin{array}{l}8.7 \%(5.1- \\
13.74)\end{array}$ & & \\
\hline \multirow[t]{3}{*}{ Parity } & Nulliparous & 106 & 12 & $\begin{array}{l}11.3 \%(5.9- \\
18.94)\end{array}$ & \multirow[t]{3}{*}{3.088} & \multirow[t]{3}{*}{0.214} \\
\hline & $<2$ parity & 35 & $\begin{array}{l}2.9 \%(0.1- \\
14.9)\end{array}$ & & & \\
\hline & $\geq 2$ parity & 84 & 6 & $\begin{array}{l}7.1 \%(2.7- \\
14.9)\end{array}$ & & \\
\hline \multirow[t]{4}{*}{ Herd size } & $\begin{array}{l}11-25 \\
\text { animals }\end{array}$ & 27 & 12 & $\begin{array}{l}44.4 \% \\
(25.5- \\
64.7)\end{array}$ & \multirow[t]{4}{*}{0.086} & \multirow[t]{4}{*}{0.769} \\
\hline & & 135 & 12 & $\begin{array}{l}8.9 \%(4.7- \\
15.0)\end{array}$ & & \\
\hline & 1-10animals & 18 & 7 & $\begin{array}{l}38.9 \% \\
(17.3- \\
64.3)\end{array}$ & & \\
\hline & & 90 & 7 & $\begin{array}{l}7.8 \%(3.2- \\
15.4)\end{array}$ & & \\
\hline \multirow[t]{2}{*}{$\begin{array}{l}\text { Reproductive } \\
\text { problems }\end{array}$} & $\begin{array}{l}\text { No } \\
\text { reproductive } \\
\text { problem }\end{array}$ & 192 & 7 & $\begin{array}{l}3.6 \%(1.5- \\
7.4)\end{array}$ & \multirow[t]{2}{*}{29.729} & \multirow[t]{2}{*}{0.000} \\
\hline & Abortion & 13 & 7 & $\begin{array}{l}53.8 \% \\
(25.1- \\
80.8)\end{array}$ & & \\
\hline
\end{tabular}




\begin{tabular}{|c|c|c|c|c|c|c|}
\hline \multirow[t]{2}{*}{ Variable } & \multirow[t]{2}{*}{ Categories } & \multirow{2}{*}{$\begin{array}{l}\text { No. of } \\
\text { examined } \\
\text { animals }\end{array}$} & \multirow{2}{*}{$\begin{array}{l}\text { No. of } \\
\text { Positive } \\
\text { Animals }\end{array}$} & \multirow{2}{*}{$\begin{array}{l}\text { Prevalence } \\
(95 \% \mathrm{Cl})\end{array}$} & \multicolumn{2}{|c|}{$\chi 2$ analysis } \\
\hline & & & & & $\begin{array}{l}\chi^{2} \\
\text { value }\end{array}$ & $\begin{array}{l}\mathrm{p} \text { - } \\
\text { value }\end{array}$ \\
\hline & $\begin{array}{l}\text { Repeat } \\
\text { breeding }\end{array}$ & 20 & 5 & $\begin{array}{l}25.0 \% \\
(8.7-49.1)\end{array}$ & & \\
\hline \multirow[t]{2}{*}{$\begin{array}{l}\text { Introduction of } \\
\text { new animals }\end{array}$} & No & 177 & 18 & $\begin{array}{l}10.2 \% \\
(6.1-15.6)\end{array}$ & 3.193 & 0.084 \\
\hline & Yes & 48 & 1 & $\begin{array}{l}2.1 \%(0.1- \\
11.1)\end{array}$ & & \\
\hline \multirow[t]{2}{*}{$\begin{array}{l}\text { Breeding } \\
\text { system }\end{array}$} & Natural & 69 & 0 & $\begin{array}{l}0.0 \%(0.0- \\
0.0)\end{array}$ & 9.179 & 0.002 \\
\hline & $\mathrm{Al}$ & 156 & 19 & $\begin{array}{l}12.2 \% \\
(7.5-18.4)\end{array}$ & & \\
\hline \multirow[t]{3}{*}{ Farming system } & Extensive & 69 & 0 & $\begin{array}{l}0.0 \%(0.0- \\
0.0)\end{array}$ & 28.923 & 0.00 \\
\hline & Intensive & 110 & 6 & $\begin{array}{l}5.5 \%(2.0- \\
11.5)\end{array}$ & & \\
\hline & $\begin{array}{l}\text { Semi- } \\
\text { intensive }\end{array}$ & 46 & 13 & $\begin{array}{l}28.3 \% \\
(16.0-43.5)\end{array}$ & & \\
\hline \multicolumn{2}{|l|}{ Overall prevalence } & 225 & 19 & $\begin{array}{l}8.4 \%(5.2- \\
12.9)\end{array}$ & & \\
\hline
\end{tabular}

Cows with history of abortions were almost thirty one times (OR: $30.83 ; 95 \% \mathrm{Cl}: 8.19-116.13, \mathrm{P}=0.000$ ) more likely to be infected with BVDV than cows with no history of reproductive problems and cows with problems of repeat breeder were nine times (OR: 8.8; $\mathrm{Cl}$ : 2.49-31.14, $\mathrm{P}=0.001$ ) more likely to be infected with BVDV than cows with no reproductive problems. Cattle in the intensive farming system were 0.15 times (OR: $0.146,95 \% \mathrm{Cl}: 0.02-0.416, \mathrm{P}=0.000)$ more likely to be infected with BVDV than cattle in the semi-intensive and extensive farming system or cattle rears in intensive farming system were $85 \%$ less likely to be infected by BVDV than cattle lives in the semi-intensive and extensive farming systems (Table 2).

However, sex, herd size, parity, age, introduction of new animals, breed and breeding methods were not statistically associated with BVDV seroprevalence $(P>0.05)$ (Table 2$)$. In age category, young animals (6-18 months) were 2.5 times (OR: $2.5 ; 95 \% \mathrm{Cl}$ : $0.94-6.58, \mathrm{P}=0.066)$ more likely to be infected with BVDV than adult (> 18 months) animals or adult age group were 2.5 times less likely to be infected by BVDV than young age group of animals. Cross breed cattle were 1.21 (OR: $1.21,95 \% \mathrm{Cl}$ : $0.34-4.35, \mathrm{P}=0.774$ ) times more likely to be infected by BVDV than local breed cattle.

In parity categories, cow with $<2$ parity were 0.23 times (OR: $0.23, \mathrm{Cl}: 0.03-1.84, \mathrm{P}=0.166$ ) more likely to be infected by BVDV than Nulliparous or cow with $<2$ parity were $77 \%$ less likely to be infected by BVDV than Nulliparous cows. Cow with $\geq 2$ parity were 0.60 times (OR: $0.603, \mathrm{Cl}: 0.22-1.68, \mathrm{P}=0.333$ ) less 
likely to be infected by BVDV than no parity or parity greater than two $39.7 \%$ less likely to be infected by BVDV than Nulliparous cows. In other word, cows with no history of parity were 4.34 and 1.67 times more likely to be infected with BVDV than cow with $<2$ and $\geq 2$ parity, respectively. Herd size 1-10 cattle were 0.795 times (OR: $0.795, \mathrm{Cl}: \mathrm{P}=0.769$ ) more likely to be infected by BVDV than herd size 11-25 cattle. Farms with history of introduction of new animal were 0.19 times (OR:0.188, $0.024-1.445, P=0.108)$ more likely infected by BVDV than farms with no history of introduction of new animals or introduction of new animals in the farm were $81.2 \%$ less likely to be infected by BVDV than farms with no history of introduction of new animals (Table 2). 
Table 2

Univariate Logistic Regression analysis results for association of potential risk

\begin{tabular}{|c|c|c|c|c|c|}
\hline \multirow[t]{2}{*}{ Variables } & \multirow[t]{2}{*}{ Categories } & \multirow[t]{2}{*}{$\begin{array}{l}\text { Examined } \\
\text { animals }\end{array}$} & \multirow[t]{2}{*}{$\begin{array}{l}\text { Positive } \\
\text { animals }\end{array}$} & \multicolumn{2}{|l|}{$\begin{array}{l}\text { Univariate logistic } \\
\text { regression }\end{array}$} \\
\hline & & & & $\begin{array}{l}\text { Crude OR (95\% } \\
\mathrm{Cl})\end{array}$ & $\begin{array}{l}\text { P- } \\
\text { Value }\end{array}$ \\
\hline \multirow[t]{2}{*}{ Sex } & Female & 204 & 19 & * & * \\
\hline & Male & 21 & 0 & $0.00(0.00-\infty)$ & 0.998 \\
\hline \multirow[t]{2}{*}{ Age } & Adult & 129 & 7 & * & * \\
\hline & Young & 96 & 12 & $\begin{array}{l}2.49(0.941- \\
6.59)\end{array}$ & 0.066 \\
\hline \multirow[t]{2}{*}{ Breed } & Local & 41 & 3 & * & * \\
\hline & Cross & 184 & 16 & $1.21(0.34-4.35)$ & 0.774 \\
\hline \multirow[t]{3}{*}{ Parity } & Nulliparous & 106 & 12 & * & * \\
\hline & $<2$ parity & 35 & 1 & $0.23(0.03-1.84)$ & 0.166 \\
\hline & $\geq 2$ parity & 84 & 6 & $0.60(0.22-1.68)$ & 0.333 \\
\hline \multirow[t]{4}{*}{ Herd size } & $11-25$ animals & 27 & 12 & * & * \\
\hline & & 135 & 12 & & \\
\hline & 1-10animals & 18 & 7 & $\begin{array}{l}0.795(0.25- \\
0.55)\end{array}$ & \\
\hline & & 90 & 7 & $0.86(0.33-2.29)$ & 0.769 \\
\hline \multirow[t]{3}{*}{$\begin{array}{l}\text { Reproductive } \\
\text { problem }\end{array}$} & $\begin{array}{l}\text { No reproductive } \\
\text { problem }\end{array}$ & 192 & 7 & * & * \\
\hline & Abortion & 13 & 7 & $\begin{array}{l}30.83(8.19- \\
116.13)\end{array}$ & 0.000 \\
\hline & Repeat breeding & 20 & 5 & $\begin{array}{l}8.81(2.49- \\
31.14)\end{array}$ & 0.001 \\
\hline \multirow{2}{*}{$\begin{array}{l}\text { Introduction of new } \\
\text { animals }\end{array}$} & No & 177 & 18 & * & * \\
\hline & Yes & 48 & 1 & $\begin{array}{l}0.188(0.024- \\
1.45)\end{array}$ & 0.108 \\
\hline \multirow[t]{2}{*}{ Breeding system } & Normal & 69 & 0 & * & * \\
\hline & Al & 156 & 19 & $\begin{array}{l}22404392(0.000- \\
\infty)\end{array}$ & 0.997 \\
\hline Farming system & Extensive & 69 & 0 & * & * \\
\hline
\end{tabular}




\begin{tabular}{|llllll|}
\hline Variables & Categories & $\begin{array}{l}\text { Examined } \\
\text { animals }\end{array}$ & $\begin{array}{l}\text { Positive } \\
\text { animals }\end{array}$ & \multicolumn{2}{l|}{$\begin{array}{l}\text { Univariate logistic } \\
\text { regression }\end{array}$} \\
\cline { 5 - 6 } & & & $\begin{array}{l}\text { Crude OR }(95 \% \\
\text { Cl })\end{array}$ & $\begin{array}{l}\text { P- } \\
\text { Value }\end{array}$ \\
\hline Intensive & 110 & 6 & $0.15(0.05-0.42)$ & 0.000 \\
\hline Semi-intensive & 46 & 13 & $0.00(0.000-\infty 0)$ & 0.997 \\
\hline
\end{tabular}

*=Reference category

Multivariable logistic regression procedures were used to model the effects of potential risk factors on outcome variables (BVDV antibodies). The forward elimination procedure was used to eliminate the factors that were not significant at $p<0.05$ in the overall model. Factors that were significant $(P<0.05)$ were retained in the final model and model fit was examined by post-estimation goodness-of-fit tests, namely the Hosmer-Lemeshow test [32]. Finally, those variables with $\mathrm{P}<0.05$ (adjusted $\mathrm{OR}, 95 \% \mathrm{Cl}$ ) were considered as a significant potential risk factors for BVDV antibody seropositive results. The final multivariable logistic regression model showed that, reproductive problem and farming system were independently associated with BVDV seroprevalence $(P<0.05)($ Table 3$)$.

Table 3

Multivariate Logistic Regression analysis results for association of potential risk factors

\begin{tabular}{|c|c|c|c|c|}
\hline \multirow[t]{2}{*}{ Variable } & \multirow[t]{2}{*}{ Categories } & \multirow{2}{*}{$\begin{array}{l}\text { Prevalence at } \\
95 \% \mathrm{Cl}\end{array}$} & \multicolumn{2}{|l|}{$\begin{array}{l}\text { Multivariate logistic } \\
\text { regression }\end{array}$} \\
\hline & & & $\begin{array}{l}\text { Adjusted OR (95\% } \\
\text { Cl) }\end{array}$ & $\begin{array}{l}\text { P- } \\
\text { Value }\end{array}$ \\
\hline \multirow[t]{3}{*}{$\begin{array}{l}\text { Reproductive } \\
\text { problems }\end{array}$} & $\begin{array}{l}\text { No history of reproductive } \\
\text { problem }\end{array}$ & $3.6 \%(1.5-7.4)$ & * & * \\
\hline & Abortion & $\begin{array}{l}53.8 \%(25.1- \\
80.8)\end{array}$ & $30.5(6.28-148.1)$ & 0.000 \\
\hline & Repeat breeding & $\begin{array}{l}25.0 \%(8.7- \\
49.1)\end{array}$ & $6.95(1.68-28.71)$ & 0.007 \\
\hline \multirow[t]{3}{*}{ Farming system } & Extensive & $0.0 \%(0.0-0.0)$ & * & * \\
\hline & Intensive & $5.5 \%(2.0-11.5)$ & $0.13(0.03-0.44)$ & 0.001 \\
\hline & Semi-intensive & $\begin{array}{l}28.3 \%(16.0- \\
43.5)\end{array}$ & $0.000(0.000-\infty)$ & 0.997 \\
\hline
\end{tabular}

*=Reference category

\section{Discussions}

In the present study, an individual and farms level seroprevalence of $8.4 \%$ and $22.2 \%$ was recorded, respectively. The animal level seroprevalence of the present study was comparable to previous reports of 
[22] with overall- seroprevalence of $11.46 \%$ in three agro ecological zones of Ethiopia. Seroprevalence of $9.59 \%, 6.11 \%$, and $16.6 \%$ were reported by [22] in Jimma, Shoa, and Southwest Shoa zones, respectively. A study conducted by [23] was reported a seroprevalence of $11.7 \%$ in breeding and dairy farms of central and southern Ethiopia and comparable to present study. The current finding was in agreement with previous report in Sudan and Egypt with $10.7 \%$ and $10.4 \%$ seroprevalence by [33] and [34], respectively. On the other hand, the present finding was lower than the finding reported by [25], [24] and [26] with seroprevalence of $32.6 \%, 32.9 \%$ and $51.9 \%$, respectively in dairy cattle in Ethiopian. The present finding also disagrees with reported seroprevalence of $19.8 \%$ in Kenya, $27 \%$ in Ecuador, $36 \%$ in Colombia, and $40 \%$ in Egypt by [35], [36], [37] and [38] respectively in different parts of the world. However, the present finding was higher prevalence compare to the prevalence of $2.2 \%$ and $7.76 \%$ reported by [39] and [40] in Nepal, respectively. The variation of seroprevalence in different countries and regions might be due to the differences in management system (grazing practice, herd size, livestock trade, contact with other ruminants, biosecurity measures), types of diagnostic tests used, sample size, study design and environmental condition $[41,42,17]$.

The present finding was the smallest seroprevalence reported when compared with the different studies in Ethiopia and much lower from the reported prevalence of $78.8 \%$ in Mexico, $77.9 \%$ in Iran, $64.4 \%$ in Nigeria, 61.6\% in Croatia, 51.1\% in Bangladesh and 33.2 in Malaysia by [43], [44], [45], [46], and [47], respectively in different parts of the world. The low prevalence of the present study might be due to differences in sample size, sampling frame, study periods, breeds of animals, cattle management systems and the specificity and sensitivity of the kits used. The antibodies detected in these countries might be due to vaccination as opposed to situation in Ethiopia where there is no vaccination.

Many studies conducted in different countries reported that a herd is more likely to have persistently infected cattle if they are simultaneously farming with small ruminants [48] or contact with wild animals $[49,50]$. In area residing with high cattle density is likely to lead to increased prevalence of antibody [19]. Many studies indicated that prevalence was higher in large herds than in small herds $[51,52]$. This was comparable with the present study with $44.4 \%$ and $38.9 \%$ in $11-25$ animals and $1-10$ animals herd size, respectively.

The higher proportions of cows with history of abortions were seropositive to BVDV compared with no history of reproductive problem $53.8 \%(25.1-80.8) ; P<0.05)$, that was cows with history of abortion were thirty times (adj OR: $30.5 ; P=0.000$ ) more likely to be infected than cows with no history of reproductive problem. This result was in agreement with other studies that reported higher prevalence of BVDV antibody in cows with history of abortions than cows with no history of reproductive problem $[23,53,26]$. This results also in agreement with [54] and [40] in which findings shows that there was significant association between abortion and seropositivity with $O R=14.21$ and $O R=6.33$, respectively. In this study, the higher seroprevalence was observed in cows with history of repeat breeder compared to the cows with history of no reproductive problem $25.0 \%(8.7-49.1) ; P<0.05)$ and repeat breeder were seven times (adj OR: $6.95 ; p=0.007$ ) more likely to be infected than animals with no history of reproductive problem, which were higher than reports from [26]. This result is in line with previous findings in Ethiopia [22, 24]. 
This results disagree with [26] and [53] in which higher seroprevalence was observed in cows with history of repeat breeding compared to the cows with history of abortion.

BVD infection of naive pregnant cows and heifers has been reported to lead to reproductive disorders such as early embryonic death, fetal death and mummification, birth of calves with congenital defects, calves with poor growth rates, increased age at first calving and depressed ovarian function in affected herds $[55,56]$. Bovine viral diarrhea virus has also been reported to be fetopathogenic in cattle, thus leading to early embryonic death, repeat breeder syndrome and abortion in cattle. If exposure and transient infection of the dam occurs prior to embryo attachment to the endometrium, infection is avoided as BVDV does not penetrate the zona pellucida. However, following attachment embryonic infection can occur and may lead to embryo loss with the dam returning to heat [57].

In this study, the higher seroprevalence was observed in semi-intensive farming system $28.3 \%$ as compared to intensive farming system. Cows in intensive farming system were 0.13 times (adj OR: 0.13; $P=0.001)$ more likely to be infected with BVDV than cows in extensive and semi-intensive farming system or cows in the intensive farming system $87 \%$ less likely to be infected with BVDV than cows in the extensive farming system. This result is in agreement with previously reported in Mexico by [43]. This might be that, cows in an intensive system where contact between animals from different herds is not common and entrance of animals from different sources is not frequent, the prevalence is high than extensive and semi-intensive or double purpose farm. This may due to a high rate of contact between animals within intensively managed herds, that facilitating the transmission of infections among the animals. Therefore, conditions in the extensive and semi-intensive farming systems for the pathogen are adverse and have less probable transmission than in the intensive system.

In current study, herd seroprevalence of $22.2 \%$ were reported. This finding disagree with $69.8 \%$ and $95.6 \%$ herd seroprevalence were reported by $[25,26]$ respectively in Ethiopia. This finding also disagree with herd seroprevalence of $65.5 \%$ in Brazil, $66 \%$ in Great Britain, $69 \%$ in Colombia and $92 \%$ in Cameron were reported by [58], [59], [37], and [49] respectively in different parts of the world. This might be due to their sampling focused on dairy animals with history of reproductive disorders. However, on the current study it is not possible to confirm PI status and tell the genotype of BVDV that might be predominant, whether BVDV- 1 or BVDV- 2 .

\section{Conclusion}

The present study demonstrated that BVDV infection was less-spread in dairy herds in and around Asella town, Ethiopia. It also suggested that the importance of BVDV might be not growing in Ethiopia as the seroprevalence recorded was much lower than a couple of earlier reports from the country. This study was found $8.4 \%$ and $22.2 \%$ seroprevalence at an individual level and herd level respectively. The higher seroprevalence was estimated in abortion categories, cows with history of repeat breeding compared to cows with no reproductive problem and semi-intensive farming system to intensive farming system. Among other suspected risk factors for BVDV infection, farming system and animals with history of 
reproduction problems were potential risk factors for BVD in and around Asella town dairy farms. Isolate repeat breeder and cows with abortion history from herds in order to minimize the risk of viral spread in their herds, Vaccine must be used by inroducing appropriate vaccine type in Ethiopia and Farmers and owner of dairy farms need to be awered of the severity of the disease.

\section{Abbreviations}

\section{Al}

artificial insemination; BVD:Bovine viral diarrhea; BVDV:Bovine viral diarrhea virus; CP:cytopathic; CSA:central statistics agency; iELISA:indirect Enzyme linked immunoassay; NAHDIC:National Animal Health Diagnostic and Investigation center; NCP:non-cytopathic; OR:odd ratio; PCR:Polymerase chain reaction; PI:persistently infected; VIF:Variance inflation factors

\section{Declarations}

\section{Ethics approval and consent to participate}

Approval for this study was given from Haramaya University ethical review board. Informed consent was received from all the willing participating farmers and farm managers. The information collected for this study was not a sensitive nature, and the procedures performed on the animals being minimally invasive (rectal palpation and collection of blood samples from the coccygeal vein). Only farmers/farms willing to participate in the study were recruited after giving informed written consent, after the objectives as well as the potential benefits of performing this study to the Ethiopian dairy industry were explained to them in detail. All methods were carried out in accordance with relevant guideline and regulation and a study was carried out in compliance with the ARRIVE guidelines.

\section{Consent for publication}

Not applicable

\section{Availability of data and materials}

The datasets used and/or analyzed during the study are available from the corresponding author on reasonable request.

\section{Competing interests}

The authors declare that none of them have financial or personal relationships with individuals or organizations that may have inappropriately influenced them in writing this paper and, therefore, declare that there is no competing interest.

\section{Funding}


No funding was obtained for this study

\section{Author contributions}

AL designed the study, did the fieldwork, analyzed the data and drafted the manuscript. AT provide BVDV serological kits. AT, DG, SG, and CD did the laboratory works and participated in the write-up. PW and FT supervised the study, assisted data analysis and interpretation and enriched the manuscript. All authors have read and approved the final manuscript.

\section{Acknowledgments}

The authors would like to acknowledge Dr. Asaminew Tesfaye for providing the BVDV serological kits and Asella Veterinary Regional Laboratory and National Animal Health Diagnostic and Investigation center (NADHIC), Ethiopia, for allowing its laboratory facility. Furthermore, all private and commercial dairy farms owners and livestock health and productions professionals in Tiyo district and Assela town are very much appreciated for their cooperation and provision of valuable data.

\section{Author details}

${ }^{1}$ field veterinarian, Oromia livestock and Fishery development office of Tiyo district, Arsi Zone, Oromia region, Ethiopia. ${ }^{2}$ Haramaya University, College of Veterinary Medicine, P.O. Box: 138, Dire Dawa, Ethiopia.

${ }^{3}$ National Animal Diagnostic and Investigation Center (NAHDIC), P.O. Box: 04, Sebeta, Ethiopia. ${ }^{4}$ Addis Ababa University, School of Veterinary medicine, P.O. Box: 34, DebreZeit, Ethiopia

\section{References}

1. Moennig V, Eicken K, Flebbe U, Frey HR, Grummer B, Haas L, Greiser-Wilke I, Liess B. Implementation of two-step vaccination in the control of bovine viral diarrhoea (BVD). Preventive veterinary medicine. 2005; 72:109-14.

2. Richter V, Kattwinkel E, Firth CL, Marschik T, Dangelmaier M, Trauffler M, Obritzhauser W, Baumgartner W, Käsbohrer A, Pinior B. Mapping the global prevalence of bovine viral diarrhoea virus infection and its associated mitigation programmes. The Veterinary record. 2019; 184(23): 711.

3. Burgstaller J, Obritzhauser W, Kuchling S, Kopacka I, Pinior B, Köfer J. The effect of bovine viral diarrhoea virus on fertility in dairy cows: Two case-control studies in the province of Styria, Austria. Berliner Und Münchener Tierärztliche Wochenschrift. 2016); 129: 103-10.

4. Richter V, Lebl K, Baumgartner W, Obritzhauser W, Käsbohrer A, Pinior B. A systematic worldwide review of the direct monetary losses in cattle due to bovine viral diarrhoea virus infection. The Veterinary Journal. 2017; 220:80-7.

5. Pinior B, Firth CL, Richter V, Lebl K, Trauffler M, Dzieciol M, Hutter SE, Burgstaller J, Obritzhauser W, Winter P, Käsbohrer A. A systematic review of financial and economic assessments of bovine viral 
diarrhea virus (BVDV) prevention and mitigation activities worldwide. Preventive veterinary medicine. 2017; 137:.77-92.

6. Pinior B, Firth CL. The economics of bovine viral diarrhoea eradication. The Veterinary Record. 2017; 181(11): 300.

7. Scharnböck B, Roch FF, Richter V, Funke C, Firth CL, Obritzhauser W, Baumgartner W, Käsbohrer A, Pinior B. A meta-analysis of bovine viral diarrhoea virus (BVDV) prevalences in the global cattle population. Scientific reports. 2018; 8(1): 1-15.

8. Simmonds P, Becher P, Collett MS, Gould EA, Heinz FX, Meyers G, Monath T, Pletnev A, Rice CM, Stiasny K, Thiel HJ. Family flaviviridae. Virus taxonomy: Ninth report of the international committee on taxonomy of viruses. 2011; 9: 1003-1020.

9. Ridpath JF. Bovine viral diarrhea virus: global status. Veterinary Clinics: Food Animal Practice. 2010; 26(1):105-121.

10. International Office of Epizootics. Biological Standards Commission and International Office of Epizootics. International Committee. 2008. Manual of diagnostic tests and vaccines for terrestrial animals: mammals, birds and bees (Vol. 2). Office international des épizooties.

11. Peterhans E, Bachofen C, Stalder H, Schweizer M. Cytopathic bovine viral diarrhea viruses (BVDV): emerging pestiviruses doomed to extinction. Veterinary research. 2010; 41(6): 44.

12. Khodakaram-Tafti A, Farjanikish GH. Persistent bovine viral diarrhea virus (BVDV) infection in cattle herds. Iranian journal of veterinary research. 2017; 18(3): 154.

13. Fulton RW, Ridpath JF, Ore S, Confer AW, Saliki JT, Burge LJ, Payton ME. Bovine viral diarrhoea virus (BVDV) subgenotypes in diagnostic laboratory accessions: distribution of BVDV1a, 1b, and 2a subgenotypes. Veterinary microbiology. 2005; 111(1-2): 35-40.

14. Grooms DL. Reproductive consequences of infection with bovine viral diarrhea virus. The Veterinary clinics of North America. Food animal practice. 2004; 20(1): 5.

15. Blanchard PC, Ridpath JF, Walker JB, Hietala SK. An outbreak of late-term abortions, premature births, and congenital deformities associated with a bovine viral diarrhea virus 1 subtype $b$ that induces thrombocytopenia. Journal of veterinary diagnostic investigation. 2010; 22(1): 128-131.

16. Sandvik T. Selection and use of laboratory diagnostic assays in BVD control programmes. Preventive veterinary medicine. 2005; 72(1-2): 3-16.

17. Saa LR, Perea A, García-Bocanegra I, Arenas AJ, Jara DV, Ramos R, Carbonero A. Seroprevalence and risk factors associated with bovine viral diarrhea virus (BVDV) infection in non-vaccinated dairy and dual purpose cattle herds in Ecuador. Tropical animal health and production. 2012; 44(3):645-9.

18. Dubovi EJ. Laboratory diagnosis of bovine viral diarrhea virus. Biologicals. 2013; 41(1): 8-13.

19. Givens M, Daniel M, Shonda D, Marley Craig A, Jones Douglas T, Ensley Patricia K, Galik Yijing Zhang Kay P, Riddell Kellye S, Joiner Bruce W, Brodersen Soren PR. "Protective effects against abortion and fetal infection following exposure to bovine viral diarrhea virus and bovine herpesvirus 1 during pregnancy in beef heifers that received two doses of a multivalent modified-live virus vaccine prior to breeding." Journal of the American Veterinary Medical Association. 2013; 241: 484-495. 
20. Lindberg A, Houe H. Characteristics in the epidemiology of bovine viral diarrhea virus (BVDV) of relevance to control. Preventive veterinary medicine. 2005; 72(1-2): 55-73.

21. Ridpath JF. Immunology of BVDV vaccines. Biologicals. 2013; 41(1): 14-19.

22. Nigussie Z, Mesfin T, Sertse T, Fulasa TT, Regassa F. Seroepidemiological study of bovine viral diarrhea (BVD) in three agroecological zones in Ethiopia. Tropical animal health and production. 2010; 42(3): 319-321.

23. Asmare K, Regassa F, Robertson LJ, Martin AD, Skjerve E. Reproductive disorders in relation to Neospora caninum, Brucella spp. and bovine viral diarrhoea virus serostatus in breeding and dairy farms of central and southern Ethiopia. Epidemiology and Infection. 2013; 141(8): 1772-80

24. Asmare K, Sibhat B, Ayelet G, Gebremedhin EZ, Lidete KA, Skjerve E. Serological evidence of Bovine herpesvirus-1, Bovine Viral Diarrhea virus and Schmallenberg virus infections in relation to reproductive disorders in dairy cattle in Ethiopia. Acta tropica. 2018, 178: 236-241.

25. Aragaw K, Sibhat B, Ayelet G, Skjerve E, Gebremedhin EZ, Asmare K. Seroprevalence and factors associated with bovine viral diarrhea virus (BVDV) infection in dairy cattle in three milksheds in Ethiopia. Tropical animal health and production. 2018; 50(8): 1821-1827.

26. Tadesse T, Deneke Y, Deresa B. Seroprevalence of bovine viral diarrhea virus and its potential risk factors in dairy cattle of jimma town, southwestern Ethiopia. Journal of Dairy,Veterinary and Animal Research. 2019; 8: 11-17.

27. Central Statistical Agency (CSA). Report on Livestock and livestock characteristics, Agricultural sample survey, Volume II. Addis Ababa, Ethiopia. Statistical Bulletin. 2018; 587

28. Tiyo District Livestock office, 2019.

29. Thrusfield M. Veterinary epidemiology. John Wiley \& Sons. 2018

30. Otte MJ, Gumm ID. Intra-cluster correlation coefficients of 20 infections calculated from the results of cluster-sample surveys. Preventive Veterinary Medicine. 1997; 31(1-2): 147-150.

31. Hair JF, Anderson RE, Tatham RL, Black WC. Multivariate data analysis (4* ed.). (1995).

32. David WH, Stanley L. Applied Logistic Regression. Wiley Publishing. 2000.

33. Saeed IK, Ali YH, Taha KM, Mohammed NE, Nouri YM, Mohammed BA, Mohammed OI, Elmagbool SB, Elghazali F. First report of Bovine Viral Diarrhea Virus antigen from pneumonic cattle in Sudan. Journal of Advanced Veterinary and Animal Research. 2015; 2(2): 153-157.

34. Soltan MA, Wilkes RP, Elsheery MN, Elhaig MM, Riley MC, Kennedy MA. Circulation of bovine viral diarrhea virus-1 (BVDV-1) in dairy cattle and buffalo farms in Ismailia Province, Egypt. The Journal of Infection in Developing Countries. 2015; 9(12): 1331-1337.

35. Callaby R, Toye P, Jennings A, Thumbi SM, Coetzer JAW, Van Wyk IC, Hanotte O, Mbole-Kariuki MN, Bronsvoort BDC, Kruuk LEB, Woolhouse MEJ. Seroprevalence of respiratory viral pathogens of indigenous calves in Western Kenya. Research in veterinary science. 2016; 108: 120-124.

36. Herrera-Yunga V, Labada J, Castillo F, Torres A, Escudero-Sanchez G, Capa-Morocho M, AbadGuaman R. Prevalence of antibodies and risk factors to Bovine Viral Diarrea in non-vaccinated dairy 
cattle from Southern Ecuador. Tropical and Subtropical Agroecosystems. 2018; 21(1).

37. Ortega DO, Sarmiento RAM, Torreglosa JCT, Rocha JF. Prevalence and risk factors of bovine viral diarrhea in Colombian cattle. Veterinary World. 2020; 13(8): 1487.

38. Selim AM, Elhaig MM, Moawed SA, El-Nahas E. Modeling the potential risk factors of bovine viral diarrhea prevalence in Egypt using univariable and multivariable logistic regression analyses. Veterinary World. 2018; 11(3); 259.

39. Manandhar S, Yadav GP, Singh DK. Epidemiological survey of bovine viral diarrhea in dairy cattle in Nepal. OIE bulletin news feed. 2018.

40. Thapa A, Acharya MP, Raut R, Rimal S. Seroprevalence and Risk Factors of Bovine Viral Diarrhea in Improved Cattle of Chitwan, Nawalpur and Rupandehi Districts of Nepal. Nepalese Veterinary Journal. 2019; 36: 93-97.

41. Houe $H$. Epidemiological features and economic importance of bovine virus diarrhoea virus (BVDV) infections. Veterinary microbiology. 1999; 64(2-3): 89-107.

42. Talafha AQ, Hirche SM, Ababneh MM, Al-Majali AM. Prevalence and risk factors associated with bovine viral diarrhea virus infection in dairy herds in Jordan. Tropical animal health and production. 2009; 41(4): 499-506.

43. Mili\&an-Suazo F, Hern\&andez-Ort\&iz R, Hern\&andez-Andrade L, Alvarado-Islas A, D\&iaz-Aparicio E, Mej\&ia-Estrada F, Palomares-Res\&endiz EG, Reyes IBA, Zendejas-Mart\&inez H. Seroprevalence and risk factors for reproductive diseases in dairy cattle in Mexico. Journal of Veterinary Medicine and Animal Health. 2016; 8(8): 89-98.

44. Sakhaei E, Khalili M, Kazeminia S. Serological study of bovine viral respiratory diseases in dairy herds in Kerman province, Iran. Iranian Journal of veterinary research.2009: 10(1): 49-53.

45. Bello SM, Daneji Al, Chafe UM, Abubakar MB, Jibril AH, Festus A. Detection of antibodies to bovine viral diarrhea virus in cattle presented for slaughter at Sokoto metropolitan abattoir, Nigeria. Journal of Veterinary Medicine and Animal Health. 2016: 8(2): 11-14.

46. Rêgo MJP, Batista Filho AFB, de Oliveira PRF, de Melo Borges J, de França CAB, Ribeiro CP, Pituco EM, Junior JWP. Epidemiological analysis of infection by the bovine viral diarrhea virus on family farms in Brazil. Semina: Ciências Agrárias. 2016; 37(6): 4119-4130.

47. Daves L, Yimer N, Arshad SS, Sarsaifi K, Omar MA, Yusoff R, Haron AW, Abdullah FFJ. Seroprevalence of bovine viral diarrhea virus (BVDV) infection and associated risk factors in cattle in Selangor, Malaysia. Veterinary Medicine Open Journal. 2016; 1:.22-28.

48. Walz P, Smith B. Diseases of the alimentary tract. IB Smith (red.), Large animal internal medicine. 2015: 750-759.

49. Handel IG, Willoughby K, Land F, Koterwas B, Morgan KL, Tanya VN, Barend M. Seroepidemiology of bovine viral diarrhoea virus (BVDV) in the Adamawa region of Cameroon and use of the SPOT test to identify herds with PI calves. PloS one. 2011; 6(7): e21620.

50. Bedeković T, Lemo N, Barbić L, Cvetnić Ž, Lojkić I, Benić M, Čač Ž, Lojkić M, Madić J. Influence of category, herd size, grazing and management on epidemiology of bovine viral diarrhoea in dairy 
herds. Acta Veterinaria Brno. 2013: 82(2): 125-130.

51. Sarrazin S, Veldhuis A, Méroc E, Vangeel I, Laureyns J, Dewulf J, Caij AB, Piepers S, Hooyberghs J, Ribbens S, Van Der Stede Y. Serological and virological BVDV prevalence and risk factor analysis for herds to be BVDV seropositive in Belgian cattle herds. Preventive Veterinary Medicine, 2013; 108(1): 28-37.

52. Rajeev M, Mutinda M, Ezenwa, VO. Pathogen exposure in cattle at the livestock-wildlife interface. EcoHealth, 2017; 14(3): 542-551.

53. Okumu TA. Infectious abortion and associated risk factors in dairy cattle farms in Nakuru district, Kenya (Doctoral dissertation). 2014

54. Derdour SY, Hafsi F, Azzag N, Tennah S, Laamari A, China B, Ghalmi F. Prevalence of the main infectious causes of abortion in dairy cattle in Algeria. Journal of veterinary research. 2017; 61(3): 337-343.

55. Altamiranda EG, Kaiser GG, Mucci NC, Verna AE, Campero CM, Odeon AC. Effect of bovine viral diarrhea virus on the ovarian functionality and in vitro reproductive performance of persistently infected heifers. Veterinary microbiology. 2013: 165(3-4): 326-332.

56. Yang N, Cui X, Qian W, Yu S, Liu Q. Survey of nine abortifacient infectious agents in aborted bovine fetuses from dairy farms in Beijing, China, by PCR. Acta Veterinaria Hungarica, 2012; 60(1): 83-92.

57. Sibel GÜR. Prevalence of bovine viral diarrhoea, bovine herpesvirus type 1 and 4 infections in repeat breeding cows in Western Turkey. Braz. j. vet. res. anim. Sci. 2011; 48(3): 228-233.

58. Fernandes LG, de Campos Nogueira AH, De Stefano E, Pituco EM, Ribeiro CP, Alves CJ, Oliveira TS, Clementino IJ, de Azevedo SS. Herd-level prevalence and risk factors for bovine viral diarrhea virus infection in cattle in the State of Paraíba, Northeastern Brazil. Tropical animal health and production. 2016; 48(1): 157-165.

59. Velasova M, Damaso A, Prakashbabu BC, Gibbons J, Wheelhouse N, Longbottom D, Van Winden S, Green M, Guitian J. Herd-level prevalence of selected endemic infectious diseases of dairy cows in Great Britain. Journal of dairy science. 2017; 100(11): 9215-9233.

\section{Figures}




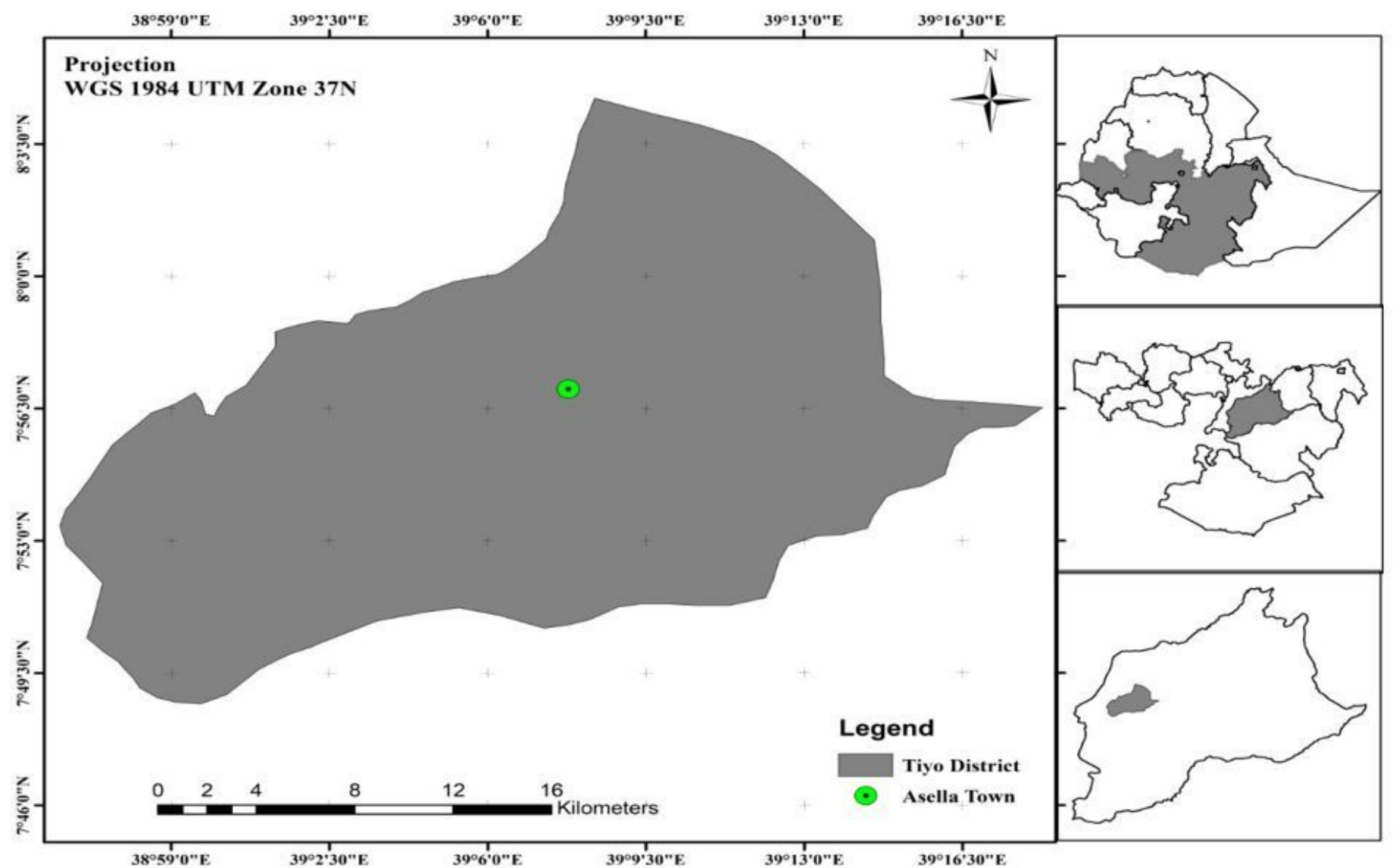

Figure 1

Map showing the Study area (Q-GIS version 3.10, http://osgeo4w-oslandia.com) Note: The designations employed and the presentation of the material on this map do not imply the expression of any opinion whatsoever on the part of Research Square concerning the legal status of any country, territory, city or area or of its authorities, or concerning the delimitation of its frontiers or boundaries. This map has been provided by the authors. 